\title{
Analisis Ketersediaan Dan Kebutuhan Ruang Terbuka Hijau Pada Kawasan Pusat Pelayanan Kota (Studi Kasus Kecamatan Palu Timur, Kota Palu)
}

\author{
ANDI CHAIRUL ACHSAN ${ }^{1^{*}}$ \\ 1. Program Studi Perencanaan Wilayah dan Kota, Jurusan Teknik Arsitektur, \\ Fakultas Teknik, Universitas Tadulako \\ Kampus Bumi Tadulako Tondo Jl. Soekarno Hatta Km. 9 Palu 94118, Indonesia \\ *E-mail: andichairulachsan@gmail.com
}

\section{ABSTRACT \\ Analysis of the Availability and Requirements of Green Open Space on Service Centre Area of The City (Case Study on Palu Timur District, Palu City)}

The development on urban growth at this time indicates unbalance movement activities, where many of it should have be able to maintain and ensure its sustainability of resources and preservation of environmental quality. One effort to minimize the negative impact of the environmental hazards against physical development in urban area is through green open space planning. The purpose of this study was to identify and analyze the needs and availability of green open space in the service center area of Palu city based on area, population and need for oxygen. The results showed that the availabilty of existing green open space in the service centre area of Palu city was 39,49 hectare and the result of green open space requirement in Palu service centre area based on area, population and need for oxygen were 180 hectare, 78,81 hectare and 43,89 hectare respectively.

Keywords : green open space, availability, needs

\section{Pendahuluan}

Perkembangan pembangunan kota saat ini menunjukkan kecenderungan terjadinya aktivitas pembangunan yang tidak seimbang (Rushayati, dkk. 2011). Pembangunan yang terjadi saat ini lebih berorientasi pada pemenuhan ruang-ruang kota dengan fasilitas maupun sarana prasarana berupa kawasan terbangun yang berisi bangunan fisik yang tidak diimbangi dengan ketersediaan ruang terbuka yang memadai khususnya ruang terbuka hijau. Aktivitas pembangunan yang tidak seimbang ini dapat berdampak negatif bagi kondisi lingkungan (Rahmy, dkk. 2012) hal ini dikarenakan pada kondisi tertentu lingkungan tidak dapat mendukung maupun mengakomodasi aktivitas perkotaan secara berlebihan sehingga mengakibatkan kualitas lingkungan menjadi terganggu. 
Wilayah perkotaan dengan dinamika perkembangannya hendaknya tetap dapat menjaga dan menjamin terpeliharanya kelestarian sumberdaya dan kualitas lingkungan. Bentuk atau model penataan kota yang dapat menciptakan kualitas lingkungan yang optimal adalah melalui penataan yang tidak hanya fokus pada pengembangan kawasan terbangun untuk fungsi-fungsi sosial maupun ekonomi tetapi juga mempertimbangkan keberadaan atau ketersediaan ruang terbuka hijau. Salah satu upaya untuk meminimalkan dampak negatif adari bahaya lingkungan terhadap pembangunan fisik wilayah perkotaan adalah melalui perencanaan ruang terbuka hijau (Nurusyah, 2007). Ruang terbuka hijau memiliki beberapa manfaat penting bagi suatu kota utamanya dalam menjamin terpeliharanya kualitas lingkungan kota disamping manfaat lain berupa manfaat sosial, ekonomi maupun perannya dalam meningkatkan kualitas visual dan estetika kota (Brahmanty, dkk. 2012).

Wilayah Kota Palu khususnya pada wilayah pusat-pusat aktivitas permukiman maupun perdagangan menunjukkan kondisi lingkungan yang belum memberikan kenyamanan yang optimal utamanya jika dilihat dari aspek kenyamanan iklim, pencemaran lingkungan maupun permasalahan kualitas estetika kota. Permasalahan pada wilayah ini tidak dapat dipisahkan dengan ketersediaan dan otpmalisasi penataan ruang terbuka hijau yang belum memadai artinya pembangunan yang dilakukan saat ini lebih fokus pada pembangunan untuk penyediaan fasilitas maupun sarana prasarana fisik belum mempertimbangkan pada pemenuhan penyediaan ruang terbuka hijau baik secara kuantitas maupun kualitas.

Optimalisasi penyediaan ruang terbuka hijau perlu dilakukan dalam rangka menjamin terpeliharanya kualitas lingkungan kota, tersedianya fasilitas publik yang dapat menyediakan wadah bagi warga untuk beraktivitas, berekreasi maupun bersosialisasi serta terciptanya kualitas visual kota yang menarik dan estetik. Dalam rangka mewujudkan optimalisasi penyediaan ruang terbuka hijau kota khususnya diwilayah Kota Palu perlu dilakukan kajian penentuan kebutuhan ruang terbuka hijau disesuaikan dengan standar atau ketentuan yang telah ditetapkan baik dari aspek luas, kesesuaian dengan jumlah penduduk maaupun dari aspek lainnya. Tujuan dari kegiatan penelitian ini adalah untuk mengidentifikasi ketersediaan ruang terbuka hijau kawasan pusat pelayanan kota, Kota Palu sekaligus menentukan kebutuhan ruang terbuka hijau kawasan pusat pelayanan kota, Kota Palu berdasarkan luas wilayah, jumlah penduduk dan kebutuhan oksigen

\section{Metode}

\subsection{Lokasi dan Waktu}

Penelitian dilakukan di wilayah pusat pelayanan kota, Kota Palu meliputi Kecamatan Palu Timur, Palu Barat, dan Palu Selatan Kota Palu, Provinsi Sulawesi Tengah. Penelitian dilaksanakan selama 4 bulan dimulai sejak bulan Januari sampai dengan April 2016. 


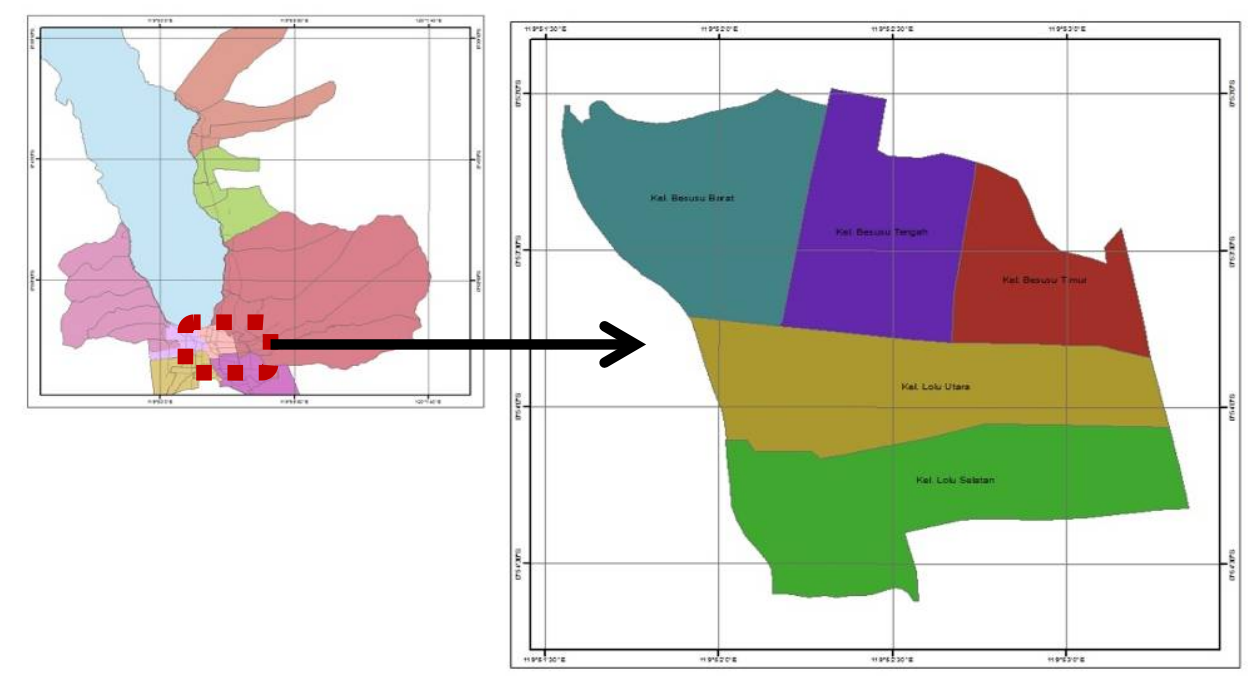

Gambar 2.1. Peta Lokasi Studi

\subsection{Alat dan Bahan}

Alat-alat yang digunakan dalam penelitian ini adalah seperangkat komputer, alat tulis dan perangkat lunak (software) untuk penyusunan naskah, pengolahan dan analisis data. Perangkat lunak yang digunakan terdiri dari ArcGIS 10, Microsoft Office dan Excell 2007. Bahan yang diperlukan untuk penelitian ini berupa citra satelit Kota Palu.

\subsection{Metode Penelitian}

Metode dalam penelitian ini meliputi pengumpulan data-data dan informasi yang diperlukan serta menganalisis data-data sesuai dengan kebutuhan dan tujuan studi.

\subsubsection{Teknik Pengumpulan Data Dan Jenis Data}

Jenis data yang diperlukan adalah data primer dan data sekunder. Data primer diperoleh dengan cara observasi ke lokasi atau obyek penelitian serta melakukan diskusi dan wawancara langsung dengan stakeholder. Data sekunder diperoleh dengan cara menelusuri berbagai sumber seperti hasil penelitian dan dokumen ilmiah dari instansi terkait.

\subsubsection{Analisis Data}

Analisis kebutuhan ruang terbuka hijau pada kawasan pusat pelayanan kota, Kota Palu meliputi analisis yang terdiri dari :

1. Analisis Ketersediaan Ruang Terbuka Hijau Kawasan Pusat Pelayanan Kota, Kota Palu

Analisa ketersediaan ruang terbuka hijau dilakukan dalam beberapa tahapan meliputi : Analisa Citra, dimana dari data citra satelit yang ada diklasifikasi menggunakan software arcgis, proses klasifikasi dilakukan dengan beberapa tahapan yaitu menginput citra kedalam software, melakukan proses komposit band citra dan selanjutnya melakukan klasifikasi dengan menggunakan teknik klasifikasi terbimbing untuk menghasilkan data kelas penggunaan lahan dalam bentuk format shapefile menentukan luas ketersediaan ruang terbuka hijau eksisting kawasan pusat pelayanan, Kota Palu berdasarkan data kelas penggunaan lahan yang dihasilkan dalam proses klasifikasi citra 
2. Analisis Kebutuhan Ruang Terbuka Hijau Pada Kawasan Pusat Pelayanan Kota, Kota Palu

Analisis kebutuhan ruang terbuka hijau kawasan pusat pelayanan Kota Palu dilakukan dengan menghitung kebutuhan ruang terbuka hijau berdasarkan luas wilayah, jumlah penduduk dan kebutuhan oksigen disesuaiakan dengan standar atau ketentuan yang ditetapkan baik yang didasarkan pada Undang-undang penataan ruang No. 26 Tahun 2007, maupun Peraturan Menteri Dalam Negeri No. 1 Tahun 2007 tentang Penataan Ruang Terbuka Hijau Kawasan Perkotaan dan Peraturan Menteri Pekerjaan Umum No. 5/PRT/M/2008 tentang Pedoman Penyediaan dan Pemanfaatan Ruang Terbuka Hijau di Kawasan Perkotaan.

\section{Hasil Dan Pembahasan}

\subsection{Analisis Ketersediaan Ruang Terbuka Hijau Kawasan Pusat Pelayanan Kota Wilayah Kecamatan Palu Timur, Kota Palu}

Hasil analisis ketersediaan ruang terbuka hijau kawasan pusat pelayanan kota wilayah Kecamatan Palu Timur, Kota Palu menunjukkan luas eksisting ruang terbuka hijau pada setiap wilayah kelurahan di wilayah Kecamatan Palu Timur Kota Palu. Luas eksisting ruang terbuka hijau pada masing-masing wilayah kelurahan meliputi wilayah Kelurahan Besusu Barat memiliki luas ruang terbuka hijau sebesar 5,96 ha, wilayah Kelurahan Besusu Tengah sebesar 2,91 ha, wilayah Kelurahan Besusu Timur sebesar 1,73 ha, wilayah Kelurahan Lolu Utara sebesar 3,55 ha dan wilayah Kelurahan Lolu Selatan sebesar 12,67 ha.

Wilayah kelurahan pada Kecamatan Palu Timur, Kota Palu yang memiliki luas eksisting ruang terbuka hijau terbesar berada pada wilayah Kelurahan Lolu Selatan dan luas eksisting ruang terbuka hijau terendah berada pada wilayah Kelurahan Besusu Timur.

Tabel 3.1 Identifikasi Ketersediaan Ruang Terbuka Hijau Kawasan Pusat Pelayanan Kota Wilayah Kecamatan Palu Timur, Kota Palu

\begin{tabular}{clccc}
\hline No & \multicolumn{1}{c}{ Kelurahan } & $\begin{array}{c}\text { Luas Wilayah } \\
\mathbf{( H a )}\end{array}$ & $\begin{array}{c}\text { Luas RTH } \\
\mathbf{( H a )}\end{array}$ & $\begin{array}{c}\text { Luas Ruang } \\
\text { Terbangun }(\mathrm{Ha})\end{array}$ \\
\hline 1 & Besusu Barat & 133 & 5,96 & 127,04 \\
2 & Besusu Tengah & 105 & 2,91 & 102,09 \\
3 & Besusu Timur & 72 & 1,73 & 70,27 \\
4 & Lolu Utara & 140 & 3,55 & 136,45 \\
5 & Lolu Selatan & 152 & 12,67 & 139,33 \\
& Jumlah & 754 & 39,49 & 714,51 \\
\hline
\end{tabular}

Sumber:Hasil analisis, 2016 


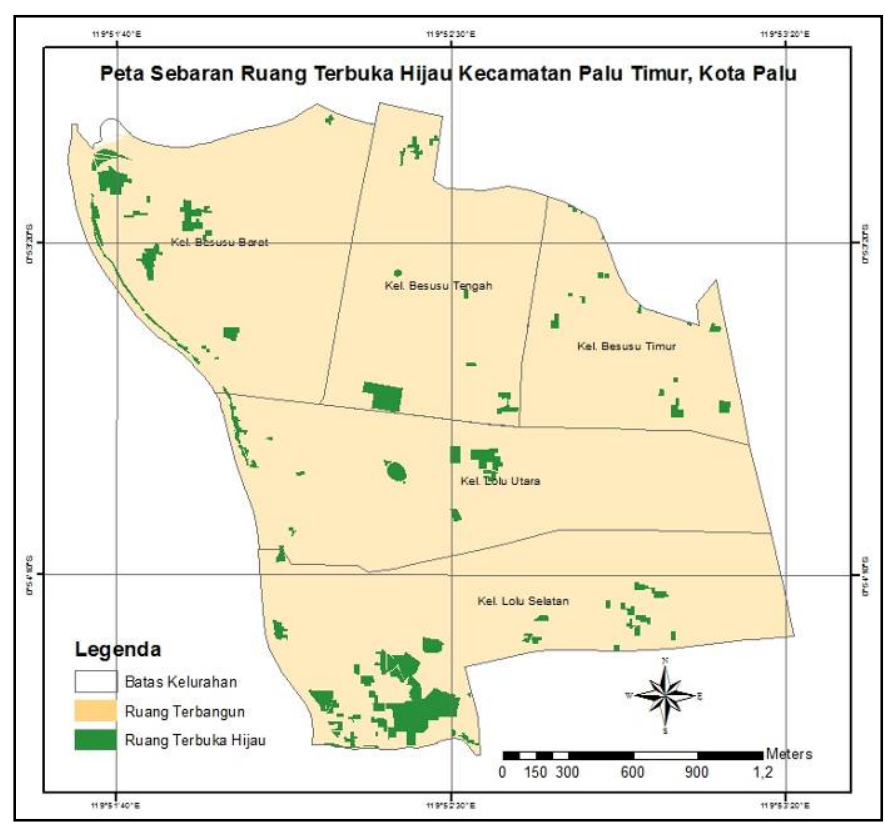

Gambar 2.2 Peta Sebaran Ruang Terbuka Hijau Kecamatan Palu Timur, Kota Palu

\subsection{Analisis Ketersediaan Ruang Terbuka Hijau Kawasan Pusat Pelayanan Kota Wilayah KecamatanPalu Timur, Kota Palu \\ 3.2.1 Analisis Kebutuhan Ruang Terbuka Hijau Berdasarkan Luas Wilayah}

Analisis kebutuhan ruang terbuka hijau berdasarkan luas wilayah pada wilayah Kecamatan Palu Timur, Kota Palu merupakan proses penentuan luas ruang terbuka hijau yang dibutuhkan berdasarkan luas wilayah perkotaan. Penentuan kebutuhan luas ruang terbuka hijau berdasarkan luas wilayah perkotaan telah diatur didalam Peraturan Menteri Pekerjaan Umum No. 5 Tahun 2008 tentang penyediaan ruang terbuka hijau wilayah perkotaan yang mengamanatkan bahwa luas ruang terbuka hijau pada wilayah perkotaan yang harus tersedia adalah $30 \%$ dari total luas wilayah dengan komposisi $20 \%$ untuk ruang terbuka hijau publik dan $10 \%$ untuk ruang terbuka hijau privat.

Berdasarkan hasil analisis penentuan kebutuhan ruang terbuka hijau berdasarkan luas wilayah pada wilayah Kecamatan Palu Timur, Kota Palu diperoleh hasil yang menunjukkan bahwa kebutuhan luas ruang terbuka hijau berdasarkan luas wilayah pada wilayah Kecamatan Palu Timur, Kota Palu adalah sebesar 180 ha, dengan komposisi untuk ruang terbuka hijau publik memiliki luas sebesar 120 ha dan untuk ruang terbuka hijau privat memiliki luas sebesar 59 ha.

Penentuan kebutuhan ruang terbuka hijau berdasarkan luas wilayah pada setiap wilayah kelurahan pada wilayah Kecamatan Palu Timur, Kota Palu diperoleh hasil yang menunjukkan kebutuhan ruang terbuka hijau pada wilayah Kelurahan Besusu Barat memiliki luas sebesar 40 ha dengan luas ruang terbuka hijau publik sebesar 27 ha dan ruang terbuka hijau privat sebesar 13 ha, Kelurahan Besusu Tengah memiliki luas sebesar 31 ha dengan luas ruang terbuka hijau publik sebesar 21 ha dan ruang terbuka hijau privat sebesar 10 ha, Kelurahan Besusu Timur memiliki luas sebesar 21 ha dengan luas ruang terbuka hijau publik sebesar 14 ha dan ruang terbuka hijau privat sebesar 7 ha, Kelurahan 
Lolu Utara memiliki luas sebesar 42 ha dengan luas ruang terbuka hijau publik sebesar 28 ha dan ruang terbuka hijau privat sebesar 14 ha, Kelurahan Lolu Selatan memiliki luas sebesar 46 ha dengan luas ruang terbuka hijau publik sebesar 30 ha dan ruang terbuka hijau privat sebesar 15 ha.

Penentuan kebutuhan ruang terbuka hijau berdasarkan luas wilayah pada wilayah Kecamatan Palu Timur, Kota Palu berdasarkan luas tertinggi dan terendah diperloeh hasil yang menunjukkan bahwa untuk kebutuhan luas ruang terbuka hijau yang terendah berada pada wilayah kelurahan Besusu Timur dengan kebutuhan ruang terbuka hijau sebesar 21 ha yang terdiri dari 14 ha untuk ruang terbukahijau publik dan 7 ha untuk ruang terbuka hijau privat dan kebutuhan ruang terbuka hijau yang tertinggi berada pada wilayah keluarahan Lolu Selatan dengan kebutuhan ruang terbuka hijau sebesar 46 ha yang terdiri dari 30 ha untuk ruang terbuka hijau publik dan 15 ha untuk ruang terbuka hijau privat.

Tabel 3.2 Analisis Kebutuhan Ruang Terbuka Hijau Kawasan Pusat Pelayanan Kota Wilayah Kecamatan Palu Timur, Kota Palu Berdasarkan Luas Wlayah

\begin{tabular}{clcccc}
\hline No & Kelurahan & $\begin{array}{c}\text { Luas } \\
\text { Wilayah } \\
(\mathbf{H a})\end{array}$ & $\begin{array}{c}\text { Kebutuhan } \\
\text { RTH (Ha) }\end{array}$ & $\begin{array}{c}\text { Kebutuhan } \\
\text { RTH (Publik) } \\
\text { (Ha) }\end{array}$ & $\begin{array}{c}\text { Kebutuhan } \\
\text { RTH (Privat) } \\
\text { (Ha) }\end{array}$ \\
\hline 1 & Besusu Barat & 133 & 40 & 27 & 13 \\
2 & Besusu Tengah & 105 & 31 & 21 & 10 \\
3 & Besusu Timur & 72 & 21 & 14 & 7 \\
4 & Lolu Utara & 140 & 42 & 28 & 14 \\
5 & Lolu Selatan & 152 & 46 & 30 & 15 \\
& Jumlah & 602 & 180 & 120 & 59 \\
\hline
\end{tabular}

Sumber: Hasil analisis, 2016

\subsubsection{Analisis Kebutuhan Ruang Terbuka Hijau Berdasarkan Jumlah Penduduk}

Analisis kebutuhan ruang terbuka hijau berdasarkan jumlah penduduk pada wilayah Kecamatan Palu Timur, Kota Palu merupakan proses penentuan luas ruang terbuka hijau yang dibutuhkan berdasarkan jumlah penduduk wilayah perkotaan. Penentuan kebutuhan luas ruang terbuka hijau berdasarkan jumlah penduduk ditentukan dengan melakukan proses perkalian antara jumlah penduduk dengan standar kebutuhan ruang terbuka hijau per penduduk.

Berdasarkan hasil analisis penentuan kebutuhan ruang terbuka hijau berdasarkan jumlah penduduk pada wilayah Kecamatan Palu Timur, Kota Palu diperoleh hasil yang menunjukkan bahwa kebutuhan luas ruang terbuka hijau berdasarkan jumlah penduduk pada wilayah Kecmatan Palu Timur, Kota Palu adalah sebesar 78,81 ha, dengan proyeksi kebutuhan pada tahun awal proyeksi sebesar 88,76 ha, dan pada tahun akhir proyeksi sebesar 119,46 ha.

Penentuan kebutuhan ruang terbuka hijau berdasarkan jumlah penduduk pada setiap wilayah kelurahan pada wilayah Kecamatan Palu Timur, Kota Palu diperoleh hasil yang menunjukkan kebutuhan ruang terbuka hijau pada wilayah Besusu Barat memiliki luas sebesar 20.47 ha dengan proyeksi kebutuhan pada tahun awal proyeksi sebesar 
23,05 ha dan pada tahun akhir proyeksi sebesar 31,03 ha, Kelurahan Besusu Tengah memiliki luas sebesar 11,67 ha dengan proyeksi kebutuhan pada tahun awal proyeksi sebesar 13,14 ha dan pada tahun akhir proyeksi sebesar 17,68 ha, Kelurahan Besusu Timur memiliki luas sebesar 11,97 ha dengan proyeksi kebutuhan pada tahun awal proyeksi sebesar 13,48 ha dan pada tahun akhir proyeksi sebesar 18,14 ha, Kelurahan Lolu Utara memiliki luas sebesar 16,40 ha dengan proyeksi kebutuhan pada tahun awal proyeksi sebesar 18,47 ha dan pada tahun akhir proyeksi sebesar 24,86 ha, Kelurahan Lolu Selatan memiliki luas sebesar 18,30 ha dengan proyeksi kebutuhan pada tahun awal proyeksi sebesar 20,61 ha dan pada tahun akhir proyeksi sebesar 27,74 ha.

Penentuan kebutuhan ruang terbuka hijau berdasarkan jumlah penduduk pada wilayah Kecamatan Palu Timur, Kota Palu berdasarkan luas tertinggi dan terendah diperloeh hasil yang menunjukkan bahwa untuk kebutuhan luas ruang terbuka hijau yang terendah berada pada wilayah kelurahan Besusu Tengah dengan kebutuhan ruang terbuka hijau sebesar 11,67 ha dan kebutuhan ruang terbuka hijau yang tertinggi berada pada wilayah Kelurahan Besusu Timur dengan kebutuhan ruang terbuka hijau sebesar 20,47 ha.

Tabel 3.3 Tabel. Analisis Kebutuhan Ruang Terbuka Hijau Kawasan Pusat Pelayanan Kota Wilayah Kecamatan Palu Timur, Kota Palu Berdasarkan Jumlah Penduduk

\begin{tabular}{clcc} 
No & Kelurahan & $\begin{array}{c}\text { Jumlah Penduduk } \\
\text { (Jiwa) }\end{array}$ & $\begin{array}{c}\text { Kebutuhan RTH Berdasarkan } \\
\text { Jumlah Penduduk Eksisting (Ha) }\end{array}$ \\
\hline 1 & Besusu Barat & 17800 & 20.47 \\
2 & Besusu Tengah & 10144 & 11.67 \\
3 & Besusu Timur & 10408 & 11.97 \\
4 & Lolu Utara & 14265 & 16.40 \\
5 & Lolu Selatan & 15917 & 18.30 \\
& Jumlah & 68534 & 78.81 \\
\hline
\end{tabular}

Sumber: Hasil analisis, 2016

Tabel 3.4 Tabel. Analisis Kebutuhan Ruang Terbuka Hijau Kawasan Pusat Pelayanan Kota Wilayah Kecamatan Palu Timur, Kota Palu Berdasarkan Proyeksi Jumlah Penduduk

\begin{tabular}{|c|c|c|c|c|c|c|c|c|c|}
\hline \multirow[t]{2}{*}{ No } & \multirow[t]{2}{*}{ Kelurahan } & \multicolumn{4}{|c|}{$\begin{array}{l}\text { Proyeksi Penduduk } \\
\text { (jiwa) }\end{array}$} & \multicolumn{4}{|c|}{$\begin{array}{c}\text { Proyeksi Kebutuhan RTH } \\
\text { Berdasarkan Jumlah Penduduk } \\
\text { (Ha) }\end{array}$} \\
\hline & & 2020 & 2025 & 2030 & 2035 & 2020 & 2025 & 2030 & 2035 \\
\hline 1 & Besusu Barat & 20045.69 & 22132.06 & 24435.59 & 26978.86 & 23.05 & 25.45 & 28.10 & 31.03 \\
\hline 2 & $\begin{array}{l}\text { Besusu } \\
\text { Tengah }\end{array}$ & 11423.79 & 12612.79 & 13925.54 & 15374.92 & 13.14 & 14.50 & 16.01 & 17.68 \\
\hline 3 & Besusu Timur & 11721.10 & 12941.04 & 14287.95 & 15775.06 & 13.48 & 14.88 & 16.43 & 18.14 \\
\hline 4 & Lolu Utara & 16064.71 & 17736.73 & 19582.79 & 21620.98 & 18.47 & 20.40 & 22.52 & 24.86 \\
\hline \multirow[t]{2}{*}{5} & Lolu Selatan & 17925.13 & 19790.79 & 21850.63 & 24124.86 & 20.61 & 22.76 & 25.13 & 27.74 \\
\hline & Jumlah & 77180.42 & 85213.41 & 94082.50 & 103874.68 & 88.76 & 98.00 & 108.19 & 119.46 \\
\hline
\end{tabular}

Sumber : Hasil analisis, 2016 


\subsubsection{Analisis Kebutuhan Ruang Terbuka Hijau Berdasarkan Jumlah Kebutuhan Oksigen}

Analisis kebutuhan ruang terbuka hijau berdasarkan kebutuhan oksigen pada wilayah Kecamatan Palu Timur, Kota Palu merupakan proses penentuan luas ruang terbuka hijau yang dibutuhkan berdasarkan oksigen yang yang dibutuhkan oleh penduduk pada wilayah perkotaan. Penentuan kebutuhan luas ruang terbuka hijau berdasarkan kebutuhan oksigen dapat dhitung dengan menggunakan pendekatan gerakis.

Berdasarkan hasil analisis penentuan kebutuhan ruang terbuka hijau berdasarkan kebutuhan oksigen pada wilayah Kecamatan Palu Timur, Kota Palu diperoleh hasil yang menunjukkan bahwa kebutuhan luas ruang terbuka hijau berdasarkan kebutuhan oksigen pada wilayah Kecamatan Palu Timur, Kota Palu adalah sebesar 43,89 ha, dengan proyeksi kebutuhan pada tahun awal proyeksi sebesar 64,06 ha, dan pada tahun akhir proyeksi sebesar 86,22 ha.

Penentuan kebutuhan ruang terbuka hijau berdasarkan kebutuhan oksigen pada setiap wilayah kelurahan pada wilayah Kecamatan Palu Timur, Kota Palu diperoleh hasil yang menunjukkan kebutuhan ruang terbuka hijau pada wilayah Kelurahan Besusu Barat memiliki luas sebesar 1,78 ha dengan proyeksi kebutuhan pada tahun awal proyeksi sebesar 16,64 ha dan pada tahun akhir proyeksi sebesar 22,39 ha, Kelurahan Besusu Tengah memiliki luas sebesar 8,42 ha dengan proyeksi kebutuhan pada tahun awal proyeksi sebesar 9,48 ha dan pada tahun akhir proyeksi sebesar 12,76 ha, Kelurahan Besusu Timur memiliki luas sebesar 8,64 ha dengan proyeksi kebutuhan pada tahun awal proyeksi sebesar 9,73 ha dan pada tahun akhir proyeksi sebesar 13,09 ha, Kelurahan Lolu Utara memiliki luas sebesar 11,84 ha dengan proyeksi kebutuhan pada tahun awal proyeksi sebesar 13,33 ha dan pada tahun akhir proyeksi sebesar 17,95 ha, Kelurahan Lolu Selatan memiliki luas sebesar 13,21 ha dengan proyeksi kebutuhan pada tahun awal proyeksi sebesar 14,88 ha dan pada tahun akhir proyeksi sebesar 20,02 ha.

Penentuan kebutuhan ruang terbuka hijau berdasarkan kebutuhan oksigen pada wilayah Kecamatan Palu Timur, Kota Palu berdasarkan luas tertinggi dan terendah diperloeh hasil yang menunjukkan bahwa untuk kebutuhan luas ruang terbuka hijau yang terendah berada pada wilayah kelurahan Besusu Barat dengan kebutuhan ruang terbuka hijau sebesar 1,78 ha dan kebutuhan ruang terbuka hijau yang tertinggi berada pada wilayah Kelurahan Lolu Selatan dengan kebutuhan ruang terbuka hijau sebesar 13,21 ha.

Tabel 3.5 Tabel. Analisis Kebutuhan Ruang Terbuka Hijau Kawasan Pusat Pelayanan Kota Wilayah Kecamatan Palu Timur, Kota Palu Berdasarkan Jumlah Kebutuhan Oksigen

\begin{tabular}{clcc}
\hline No. & \multicolumn{1}{c}{ Kelurahan } & $\begin{array}{c}\text { Jumlah Penduduk } \\
\text { (Jiwa) }\end{array}$ & $\begin{array}{c}\text { Kebutuhan RTH Berdasarkan Jumlah } \\
\text { Kebutuhan Oksigen Eksisting (Ha) }\end{array}$ \\
\hline 1 & Besusu Barat & 17800 & 1.78 \\
2 & Besusu Tengah & 10144 & 8.42 \\
3 & Besusu Timur & 10408 & 8.64 \\
4 & Lolu Utara & 14265 & 11.84 \\
5 & Lolu Selatan & 15917 & 13.21 \\
& Jumlah & 68534 & 43,89 \\
\hline
\end{tabular}

Sumber : hasil analisis, 2016 
Tabel 3.6 Analisis Kebutuhan Ruang Terbuka Hijau Kawasan Pusat Pelayanan Kota Wilayah Kecamatan Palu Timur, Kota Palu Berdasarkan Proyeksi Jumlah Kebutuhan Oksigen

\begin{tabular}{|c|c|c|c|c|c|c|c|c|c|}
\hline \multirow[t]{2}{*}{ No } & \multirow[t]{2}{*}{ Kelurahan } & \multicolumn{4}{|c|}{$\begin{array}{l}\text { Proyeksi Penduduk } \\
\text { (jiwa) }\end{array}$} & \multicolumn{4}{|c|}{$\begin{array}{c}\text { Proyeksi Kebutuhan RTH } \\
\text { Berdasarkan Kebutuhan } \\
\text { Oksigen (Ha) }\end{array}$} \\
\hline & & 2020 & 2025 & 2030 & 2035 & 2020 & 2025 & 2030 & 2035 \\
\hline 1 & Besusu Barat & 20045.69 & 22132.06 & 24435.59 & 26978.86 & 16.64 & 18.37 & 20.28 & 22.39 \\
\hline 2 & Besusu Tengah & 11423.79 & 12612.79 & 13925.54 & 15374.92 & 9.48 & 10.47 & 11.56 & 12.76 \\
\hline 3 & Besusu Timur & 11721.10 & 12941.04 & 14287.95 & 15775.06 & 9.73 & 10.74 & 11.86 & 13.09 \\
\hline 4 & Lolu Utara & 16064.71 & 17736.73 & 19582.79 & 21620.98 & 13.33 & 14.72 & 16.25 & 17.95 \\
\hline \multirow[t]{2}{*}{5} & Lolu Selatan & 17925.13 & 19790.79 & 21850.63 & 24124.86 & 14.88 & 16.43 & 18.14 & 20.02 \\
\hline & Jumlah & 77180.42 & 85213.41 & 94082.50 & 103874.68 & 64.06 & 70.73 & 78.09 & 86.22 \\
\hline
\end{tabular}

Sumber: Hasil analisis, 2016

\section{Simpulan}

Kesimpulan dari penelitian ini adalah:

1. Hasil analisis ketersediaan ruang terbuka hijau kawasan pusat pelayanan kota wilayah Kecamatan Palu Timur, Kota Palu menunjukkan luas eksisting ruang terbuka hijau pada setiap wilayah kelurahan di wilayah Kecamatan Palu Timur Kota Palu meliputi wilayah Kelurahan Besusu Barat memiliki luas ruang terbuka hijau sebesar 5,96 ha, wilayah Kelurahan Besusu Tengah sebesar 2,91 ha, wilayah Kelurahan Besusu Timur sebesar 1,73 ha, wilayah Kelurahan Lolu Utara sebesar 3,55 ha dan wilayah Kelurahan Lolu Selatan sebesar 12,67 ha.

2. Hasil analisis penentuan kebutuhan ruang terbuka hijau berdasarkan luas wilayah pada wilayah Kecamatan Palu Timur, Kota Palu diperoleh hasil yang menunjukkan kebutuhan luas ruang terbuka hijau berdasarkan luas wilayah pada wilayah Kecamatan Palu Timu, Kota Palu adalah sebesar 180 ha, dengan komposisi untuk ruang terbuka hijau publik memiliki luas sebesar 120 ha dan untuk ruang terbuka hijau privat memiliki luas sebesar 59 ha.

3. Hasil analisis penentuan kebutuhan ruang terbuka hijau berdasarkan jumlah penduduk pada wilayah Kecamatan Palu Timur, Kota Palu diperoleh hasil yang menunjukkan kebutuhan luas ruang terbuka hijau berdasarkan jumlah penduduk pada wilayah Kecmatan Palu Timur, Kota Palu adalah sebesar 78,81 ha, dengan proyeksi kebutuhan pada tahun awal proyeksi sebesar 88,76 ha, dan pada tahun akhir proyeksi sebesar 119,46 ha.

4. Hasil analisis penentuan kebutuhan ruang terbuka hijau berdasarkan kebutuhan oksigen pada wilayah Kecamatan Palu Timur, Kota Palu diperoleh hasil yang menunjukkan kebutuhan luas ruang terbuka hijau berdasarkan kebutuhan oksigen pada wilayah Kecamatan Palu Timur, Kota Palu adalah sebesar 43,89 ha, dengan proyeksi kebutuhan pada tahun awal proyeksi sebesar 64,06 ha, dan pada tahun akhir proyeksi sebesar 86,22 ha. 


\section{Daftar Pustaka}

Brahmantyo, T. Kustiwan, I. 2012. Evaluasi Penyediaan Ruang Terbuka Hijau Sebagai Infrastruktur Hijau di Kota Bogor dan Cirebon. Jurnal Perencanaan Wilayah dan Kota, 2(1): 54-60.

Laboratorium Perencanaan Lansekap. 2015. Ruang Terbuka Hijau Wilayah Perkotaan, Makalah Lokakarya Pengembangan Sistem Ruang Terbuka Hijau Di Perkotaan Dalam Rangkaian Acara Hari Bakti Pekerjaan Umum Ke 60 Direktorat Jenderal Penataan Ruang Departemen Pekerjaan Umum.

Nurisyah, S. 2007. Penataan Ruang Terbuka Hijau Pada Kota-kota Yang Rentan Bahaya Lingkungan. Makalah Penggalangan Pengembangan Ruang Terbuka Hijau Kota, Jakarta.

Peraturan Menteri pekerjaan Umum Nomor: 05/PRT/M/2008 tentang Pedoman Penyediaan dan Pemanfaatan Ruang Terbuka Hijau di Kawasan Perkotaan.

Rahmy, W.A. Faisal, B. Soeriaatmaja, A.R. 2012. Kebutuhan Ruang Terbuka Hijau Pada Kawasan Padat Penduduk Studi Kasus Wilayah Tegallega Bandung. Jurnal Lingkungan Binaan Indonesia Vol. 1 No.1 Juli 2012 hal 28-38.

Rushayati, S.B. Alikodra, H.S. Dahlan, E.N. Purnomo H. 2011. Pengembangan Ruang Terbuka Hijau Berdasarkan Distribusi Suhu Permukaan Di Kabupaten Bandung. Forum Geografi, Vol. 25 No. 1 Juli 2011 hal 17-26.

Undang-Undang Penataan Ruang Nomor 26 Tahun 2007. 